\title{
Transition Metal Catalyst Free Cross-Coupling Reaction of Tertiary Propargylic Alcohols with Hetero-Areneboronic Acids
}

Jian-Fei Bai, ${ }^{[a]}$ Jianbo Tang, ${ }^{[a, b]}$ Xiaolong Gao, ${ }^{[c]}$ Zhi-Jiang Jiang, ${ }^{[a]}$ and Zhanghua Gao*[a]

[a] Prof. J.-F. Bai, Prof. Z.-J. Jiang, J. Tang, Prof. Z. Gao

School of Biological and Chemical Engineering,

NingboTech University,

315100, Ningbo, P. R. China

E-mail: jianfei.bai@nbt.edu.cn, z.gao@nbt.edu.cn

[b] J. Tang

College of Chemistry and Chemical Engineering,

Lanzhou University,

730000, Lanzhou, P. R. China

[c] X. Gao

State Key Laboratory for Oxo Synthesis and Selective Oxidation,

Lanzhou Institute of Chemical Physics (LICP), Chinese Academy of Sciences,

730000, Lanzhou, P. R. China

Supporting information for this article is given via a link at the end of the document.

Abstract: We report a perfluorophenylboronic acid catalyzed cross coupling reaction of tertiary propargylic alcohols and hetero-areneboronic acids for valuable benzo[b]thiophene and cyclopenta[a]indene derivates. This coupling reaction proceeds efficiently with a wide array of substrates scope in up to $89 \%$ yield and excellent regioselectivity. A significant advantage of our protocol is the transition metal catalyst free and mild conditions needed. This strategy provides direct and facile access to medicinally important benzo[b]thiophene and cyclopenta[a]indene scaffold containing a quaternary carbon center.

Propargylic alcohols are easily available building blocks in organic synthesis. Because of their unique bifunctional properties (alkyne and hydroxyl), tertiary propargylic alcohols as versatile synthons can undergo cascade or multistep reactions to construct various important motif containing quaternary carbon centers ${ }^{[1]}$. As its reactivities became clear, the utility of propargylic alcohols has been greatly extended, and their chemistry has been well demonstrated in organic synthesis. Among its splendid chemistry, their combination with aryl boronic acids has triggered fruitful reaction in the construction of multi-substituted olefins $^{[2,3]}$. In 2004, Yoshida and co-workers developed a Pd-catalyzed reaction of tertiary propargylic alcohols with arylboronic acids for the construction of allenes. Diverse tetrasubstituted allenes were successfully obtained in excellent yields with good substrate compatibility ${ }^{[4]}$. Dou and Ma also successfully achieved this type of reaction with Rh- or Pd- catalysis (Scheme 1a) ${ }^{[5]}$. In 2012, Mroken and co-wrokers developed a Pd-catalyzed cross-coupling reaction of tertiary propargyl acetates and allyl boronates, 1,5-enynes were obtained in good yields with excellent levels of chirality transfer ${ }^{[6]}$. In 2019, an expeditious synthetic route to indenes from tertiary propargyl alcohols and organoboronic acids under Rh-catalysis has been reported by Dou and co-workers ${ }^{[7]}$. Indenes bearing a quaternary carbon center were obtained in good yields. In 2020, Ma and Xie independently developed 
a Mn- or Rh-catalyzed syn-hydroarylation of tertiary propargylic alcohols with aromatic boronic acids under an air atmosphere and in this reaction, a wide range of stereo-defined $(E)$-3-arylallylic alcohols were afforded

a) Previous work (transition metal catalysis)

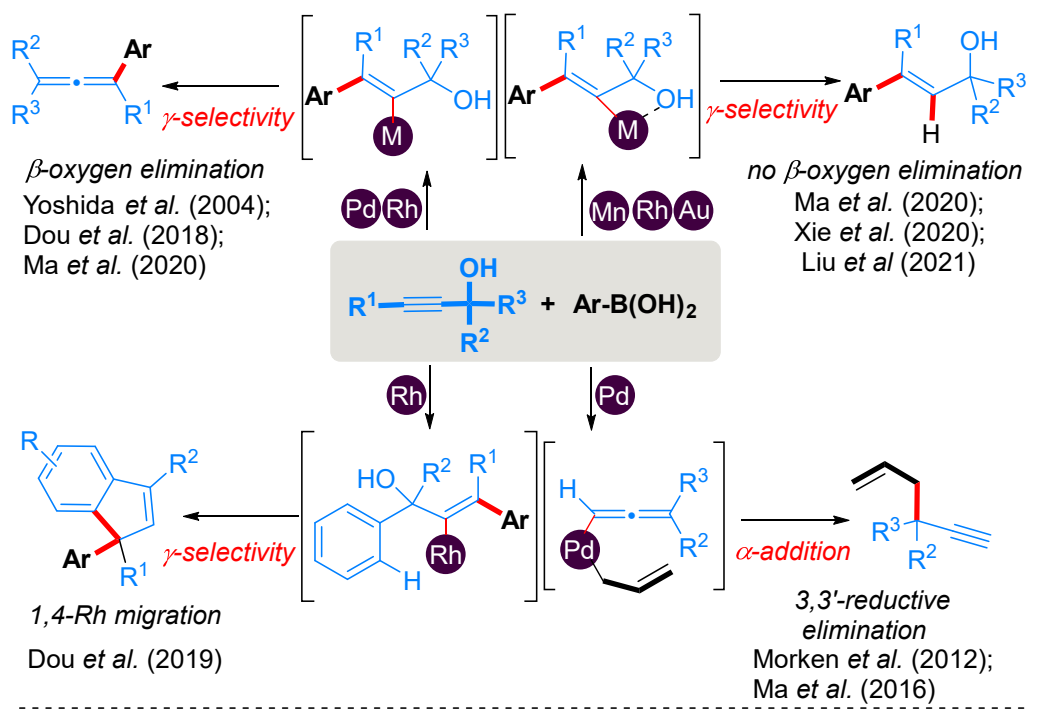

b) Our hypothesis

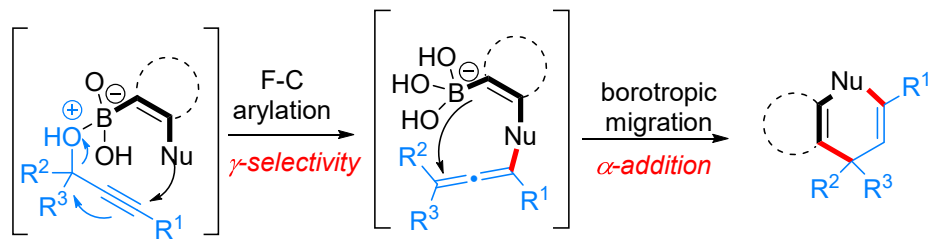

c) This work:
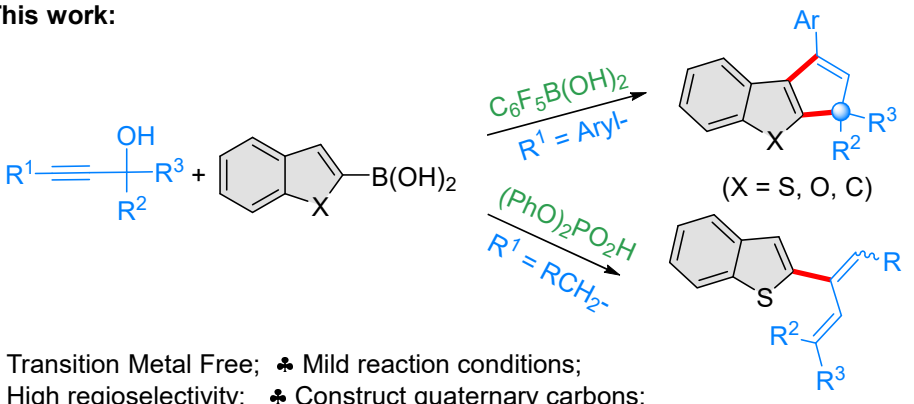

* Transition Metal Free; * Mild reaction conditions;

* High regioselectivity; * Construct quaternary carbons;

* Efficiently synthesis of benzothiophene fused derivatives

Scheme 1. The cross-coupling reaction of tertiary propargylic alcohols with (hetero)areneboronic acids.

under very mild conditions ${ }^{[8]}$. Similar results were also found in a gold-catalyzed hydroarylation of terminal propargylic alcohols with heteroareneboronic acids (Scheme 1a) [9].

Despite the progress summarized above, there are still limitations to be addressed. For example, toxic and precious metal catalysts and/or moisture-sensitive ligand have been often utilized and the loading is frequently high. The research on developing of complementary strategies and expanding the scope of transformations is imperative. To 
develop the direct coupling reaction of propargylic alcohols and aryl boronic acid, the following challenges need to be considered, which involve: 1) the interference and competition between multiple reactive functional groups in propargyl alcohols; 2) overcomeing the side reactions of substrate, such as dimeration or rearrangement of propargylic alcohols; 3 ) developing simple reaction processes and using cheap catalysts. To the best of our knowledge, no reports have been made on the nucleophilic substitution between tertiary propargylic alcohols and aryl/alkenylboronic acids under transition-metalfree conditions.

Based on our ongoing efforts on organocatalytic reaction of propargylic alcohols, ${ }^{[10]}$ we became interested in a Brønsted acid catalyzed cross-coupling reaction of propargylic alcohols and aryl/alkenylboronic acids to complement the transition metal catalysis. Because of the low intrinsic nucleophilicity, the boronic acid can not be directly add to the propargylic alcohol without metal catalysis. We hypothesized whether the substrate design could achieve the above coupling reaction. Inspired by the a-hydroxy-group-promoted Petasis-borono Mannich reaction ${ }^{[11]}$, we envisioned that using arylboronic acid containing another nucleophilc site capable of bridging propargylic alcohols and boronic acid, an intramolecular borotropic migration process with boronic acid as the nucleophile could be accomplished in the metal free condition (Scheme 1b) ${ }^{[12]}$. Furthermore, due to the steric hindrance, the first nucleophilic addition step can be carried out selectively at the $y$-position of tertiary propargylic alcohol to ensure the coupled product with high regioselectivity. In this sense, the hetero-areneboronic acids could be a suitable substrate for promoting such a transformation. Herein, we present our preliminary investigations toward an unprecedented perfluorophenylboronic acid $\left[\mathrm{C}_{6} \mathrm{~F}_{5} \mathrm{~B}(\mathrm{OH})_{2}\right]$ catalyzed regioselective crosscoupling reaction of tertiary propargylic alcohols with arylboronic acids (Scheme 1c). A serious of benzothiophenes, benzofuran and indene derivatives were obtained in good yields as well as excellent regioselectivities ${ }^{[13]}$. The application of hetero-areneboronic acid as nucleophiles offers an attractive alternative to fused benzo[b]thiophene and cyclopenta[a]indene scaffolds, which are the privileged structures in agrochemical research, material chemistry and in drug discovery (Scheme 2) ${ }^{[14]}$.

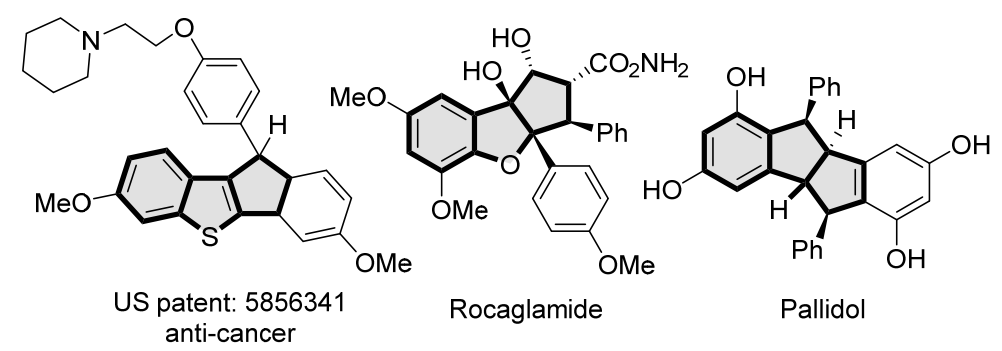

Scheme 2. Relevant natural products and bioactive molecules.

To investigate the viability of our hypothesis, we focused on the coupling reaction between $\quad \mathrm{N}$-(4-(1-hydroxy-1,3-diphenylprop-2-yn-1-yl)phenyl)acetamide (1a) and benzo[b]thiophen-2-ylboronic acid (2a). Initially, we employed $\mathrm{C}_{6} \mathrm{~F}_{5} \mathrm{~B}(\mathrm{OH})_{2}(\mathbf{4 a})$ as the catalyst, which has been demonstrated to be an effective catalyst in the propargylic 
substitution reaction ${ }^{[15]}$. To our delight, a cyclic product $3 \mathbf{a}$ afforded in $72 \%$ yield as a single isomer (Table 1, entry 1). Encouraged by this result, a series of organoborons were screened as catalysts. In the cases of $\mathrm{B}\left(\mathrm{C}_{6} \mathrm{~F}_{5}\right)_{3}(\mathbf{4 b}), 46 \%$ yield was obtained (entry 2 ), while the reactions employing $\mathrm{H}_{3} \mathrm{BO}_{3}(\mathbf{4 c})$ and $\mathrm{PhB}(\mathrm{OH})_{2}(\mathbf{4 d})$ failed to yield the product (entries 3-4). Next, a variety of Brønsted acid, including diphenyl phosphate $\left[(\mathrm{PhO})_{2} \mathrm{PO}_{2} \mathrm{H}\right.$, 4f], $p$-toluenesulfonic acid $(\mathbf{4 g})$, benzoic acid $(\mathbf{4 h})$ and $p$-nitrobenzoic acid (4i) were tested as catalysts for the studied reaction (entries 6-9), no better result was obtained. Furthermore, no conversion was observed when Lewis acids $\mathrm{Cu}(\mathrm{OTf})_{2}(\mathbf{4 j})$ and $\mathrm{AgOTf}(\mathbf{4 k})$ were utilized as catalysts (entries 10-11). These results demonstrate the unique capability of the perfluorophenylboronic acid as catalysts. Subsequently, a brief solvent screening was carried out providing better yields $(79 \%)$ in the case of 1,2-dichlorethane (DCE) as a solvent (entries 12-18), and the reaction did not proceed in $\mathrm{THF}$, dioxane and $\mathrm{CH}_{3} \mathrm{NO}_{2}$. After fine tuning the ratio of two substrates, when boronic acid $\mathbf{2} \mathbf{a}$ is slightly excessive $(1.2$ eq), the yield of $3 a$ can be up to $90 \%$ (entries 19-20). Furthermore, the reaction could still afford theproduct in a $90 \%$ yield when lowering the catalyst loading to $10 \mathrm{~mol} \%$ with extended reaction time to $36 \mathrm{~h}$ (entry 21 ).

Table 1. Optimization of the reaction conditions. ${ }^{[a]}$

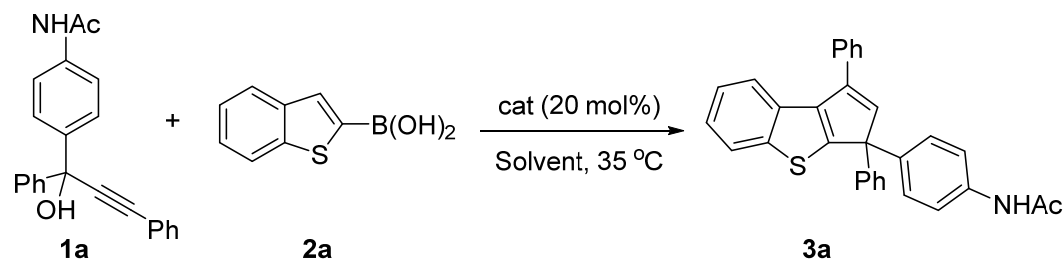

\begin{tabular}{|c|c|c|c|}
\hline Entry & Catalyst & Solvent & Yield $[\%]^{[b]}$ \\
\hline 1 & $\mathrm{C}_{6} \mathrm{~F}_{5} \mathrm{~B}(\mathrm{OH})_{2}, \mathbf{4 a}$ & $\mathrm{CH}_{2} \mathrm{Cl}_{2}$ & 72 \\
\hline 2 & $\mathrm{~B}\left(\mathrm{C}_{6} \mathrm{~F}_{5}\right)_{3}, \mathbf{4 b}$ & $\mathrm{CH}_{2} \mathrm{Cl}_{2}$ & 46 \\
\hline 3 & $\mathrm{H}_{3} \mathrm{BO}_{3}, 4 \mathrm{c}$ & $\mathrm{CH} 2 \mathrm{Cl} 2$ & N.R. \\
\hline 4 & $\mathrm{PhB}(\mathrm{OH})_{2}, \mathbf{4 d}$ & $\mathrm{CH}_{2} \mathrm{Cl}_{2}$ & N.R. \\
\hline 5 & $4-\mathrm{F}-\mathrm{C}_{6} \mathrm{H}_{4} \mathrm{~B}(\mathrm{OH})_{2}, \mathbf{4 e}$ & $\mathrm{CH}_{2} \mathrm{Cl}_{2}$ & 10 \\
\hline 6 & $(\mathrm{PhO})_{2} \mathrm{PO}_{2} \mathrm{H}, \mathbf{4 f}$ & $\mathrm{CH}_{2} \mathrm{Cl}_{2}$ & 58 \\
\hline 7 & PTSA, $\mathbf{4 g}$ & $\mathrm{CH}_{2} \mathrm{Cl}_{2}$ & 37 \\
\hline 8 & $\mathrm{PhCOOH}, \mathbf{4 h}$ & $\mathrm{CH}_{2} \mathrm{Cl}_{2}$ & N.R. \\
\hline 9 & $4-\mathrm{NO}_{2}-\mathrm{C}_{6} \mathrm{H}_{4} \mathrm{COOH}, \mathbf{4 i}$ & $\mathrm{CH}_{2} \mathrm{Cl}_{2}$ & N.R. \\
\hline 10 & $\mathrm{Cu}(\mathrm{OTf})_{2}, \mathbf{4 j}$ & $\mathrm{CH}_{2} \mathrm{Cl}_{2}$ & N.R. \\
\hline 11 & AgOTf, 4k & $\mathrm{CH}_{2} \mathrm{Cl}_{2}$ & N.R. \\
\hline
\end{tabular}




$\begin{array}{cccc}12 & \mathrm{C}_{6} \mathrm{~F}_{5} \mathrm{~B}(\mathrm{OH})_{2}, \mathbf{4 a} & \mathrm{CHCl}_{3} & 73 \\ 13 & \mathrm{C}_{6} \mathrm{~F}_{5} \mathrm{~B}(\mathrm{OH})_{2}, \mathbf{4 a} & \mathrm{ClCH}_{2} \mathrm{CH}_{2} \mathrm{Cl} & 79 \\ 14 & \mathrm{C}_{6} \mathrm{~F}_{5} \mathrm{~B}(\mathrm{OH})_{2}, \mathbf{4 a} & \text { toluene } & 59 \\ 15 & \mathrm{C}_{6} \mathrm{~F}_{5} \mathrm{~B}(\mathrm{OH})_{2}, \mathbf{4 a} & \mathrm{C}_{6} \mathrm{H}_{5} \mathrm{Cl} & 46 \\ 16 & \mathrm{C}_{6} \mathrm{~F}_{5} \mathrm{~B}(\mathrm{OH})_{2}, \mathbf{4 a} & \mathrm{THF} & \text { N.R. } \\ 17 & \mathrm{C}_{6} \mathrm{~F}_{5} \mathrm{~B}(\mathrm{OH})_{2}, \mathbf{4 a} & \text { Dioxane } & \text { N.R. } \\ 18 & \mathrm{C}_{6} \mathrm{~F}_{5} \mathrm{~B}(\mathrm{OH})_{2}, 4 \mathbf{a} & \mathrm{CH}_{3} \mathrm{NO}_{2} & \text { N.R. } \\ 19^{[c]} & \mathrm{C}_{6} \mathrm{~F}_{5} \mathrm{~B}(\mathrm{OH})_{2}, \mathbf{4 a} & \mathrm{ClCH}_{2} \mathrm{CH}_{2} \mathrm{Cl} & 90 \\ 20^{[\mathrm{dc]}]} & \mathrm{C}_{6} \mathrm{~F}_{5} \mathrm{~B}(\mathrm{OH})_{2}, \mathbf{4 a} & \mathrm{ClCH}_{2} \mathrm{CH}_{2} \mathrm{Cl} & 88 \\ 21^{[\mathrm{c}, \mathrm{e}]} & \mathrm{C}_{6} \mathrm{~F}_{5} \mathrm{~B}(\mathrm{OH})_{2}, 4 \mathbf{a} & \mathrm{ClCH}_{2} \mathrm{CH}_{2} \mathrm{Cl} & 90(86)^{[\mathrm{ff}}\end{array}$

[a] Use of $1 \mathbf{a}(0.06 \mathrm{mmol}), 2 \mathrm{a}(0.05 \mathrm{mmol})$, a catalyst $(20 \mathrm{~mol} \%)$ and a solvent $(0.5 \mathrm{~mL}), 35^{\circ} \mathrm{C}, 20 \mathrm{~h}$. [b] Determined by ${ }^{1} \mathrm{H}-\mathrm{NMR}$ with tetrabromoethane (chemical shift $\delta=5.96 \mathrm{ppm}$ ) as internal standard. [c] 1a (0.05 mmol), 2a (0.06 mmol). [d] 1a $(0.05 \mathrm{mmol}), 2 \mathrm{a}(0.075 \mathrm{mmol})$. [e] $\mathrm{C}_{6} \mathrm{~F}_{5} \mathrm{~B}(\mathrm{OH})_{2}(10 \mathrm{~mol} \%)$ was used and extend the reaction time to $36 \mathrm{~h}$. [f] Isolated yield.

With the optimized conditions (Table 1, entry 21 ), we set out assess the generality of boronic acid $\mathbf{4 a}$ catalyzed reaction of tertiary propargylic alcohols with heteroarene boronic acids. The scope of propargylic alcohols 1 was examined first (Table 2). Alcohols 1 with $\gamma$ aryl and $\gamma$-cyclopropyl substitutions worked well, giving the fused benzo[b]thiophene 3a3q in $61-89 \%$ yield with excellent regioselectivity. The electronic properties of the substituents on $y$-aryl groups of propargylic alcohols 1 have little effect on the reaction, both electron-donating ( $\mathrm{Me}$ or $\mathrm{OMe})$ and electron-withdrawing $(\mathrm{Br}$ or $\mathrm{Cl})$ groups were compatible and gave the desired products in moderate to good yields (61-89\%). The alcohols 1 bearing ortho-substituted phenyl group on the $\mathrm{y}$-position producing the cyclicproducts $\mathbf{3 i}$ and $\mathbf{3} \mathbf{I}$ in lower yield (61\% and 67\%). Propargyl alcohols 1 with different $\alpha$-aryl (4-NHTs-Phenyl, Phenyl) and a-alkyl (Methyl) were well tolerated, giving the cyclic adducts $\mathbf{3 n - 3 q}$ in good yields (68-84\%). The structure of the cyclic product $\mathbf{3 p}$ was unambiguously confirmed by single-crystal X-ray diffraction analysis ${ }^{[17]}$. $\mathrm{Y}$-Trimethylsilyl substituted propargylic alcohol was also investigated, but allene $3 \mathrm{r}$ instead of fused benzo[b]thiophene was obtained in $78 \%$ yield. Unexpectedly, entirely different regioselectivity was observed when $y$-alkyl substituted alcohols were employed, an inseparable mixture of allene and 1,3-diene was obtained. ${ }^{[18]}$ Fortunately, shifting the catalyst from boronic acid $4 \mathbf{4 a}$ to diphenyl phosphate $\mathbf{4 f}$, the 1,3 -dienes $\mathbf{3} \mathbf{s}-\mathbf{3} \mathbf{v}$ were acquired as main product with moderate to good yields.

Table 2. Scope of propargylic alcohols. ${ }^{[a]}$ 


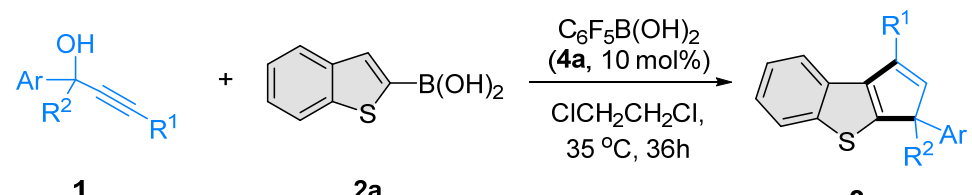

1

$2 a$
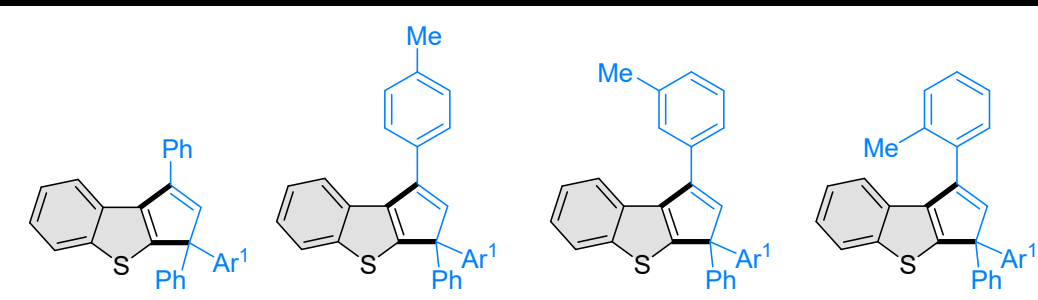

3a $(86 \%)$

3b $(87 \%)$

3c $(84 \%)$

3d (64\%)
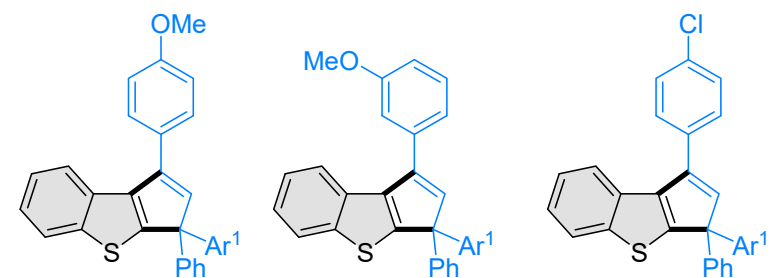

3 g (89\%)

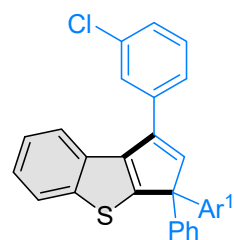

3 e $(85 \%)$

$3 \mathbf{f}(81 \%)$

3h $(82 \%)$
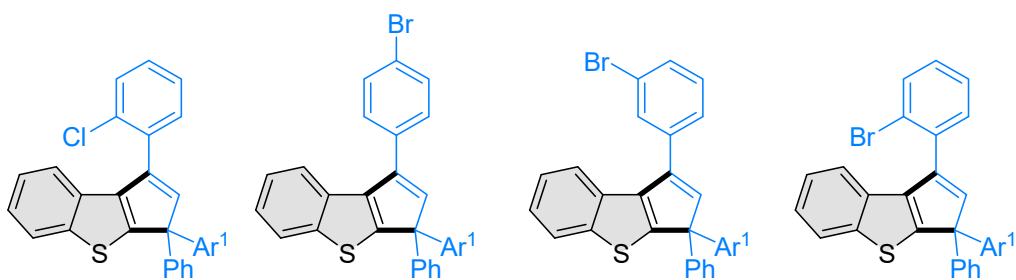

3i $(67 \%)$

3j (85\%)

3k $(80 \%)$

3I (61\%)
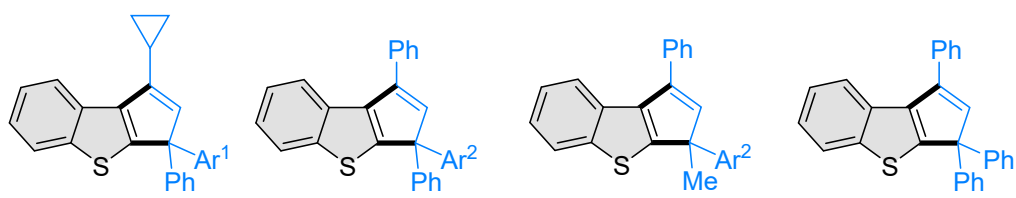

$3 \mathrm{~m}(77 \%)$

3n (84\%)

$3 \circ(68 \%)$

$3 p(82 \%)$

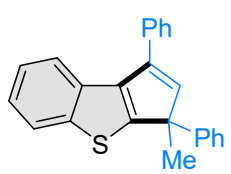

$3 q(71 \%)$
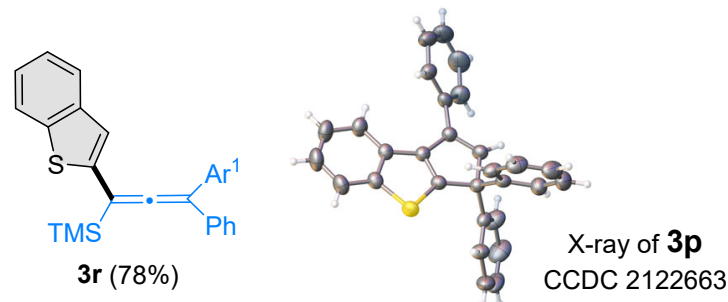


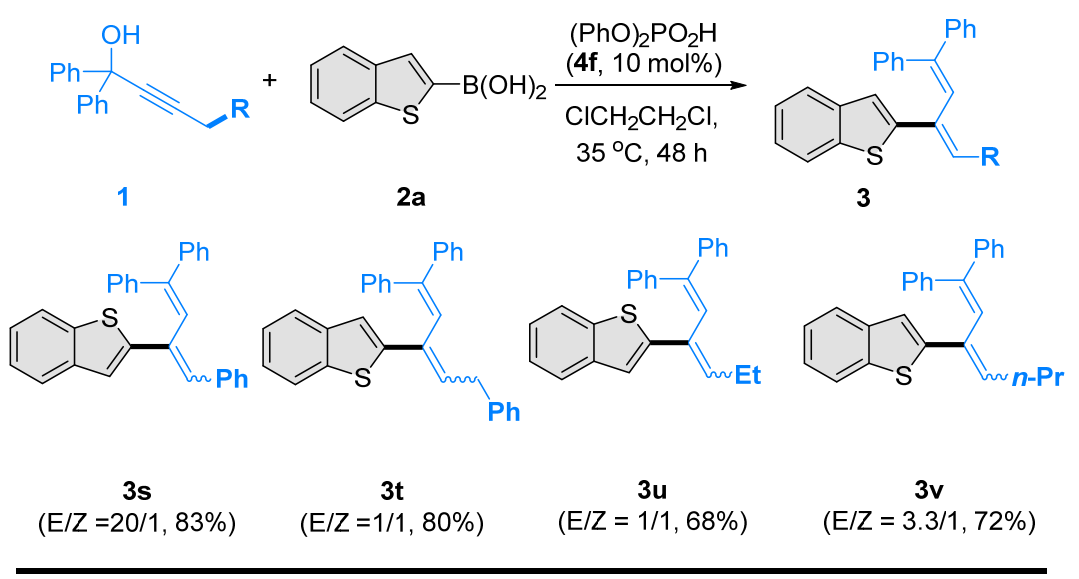

[a] Use of propylic alcohol $1(0.2 \mathrm{mmol})$, boronic acid $2 \mathrm{a}(0.24 \mathrm{mmol})$, catalyst $\mathbf{4 a}$ or $\mathbf{4 f}(0.02 \mathrm{mmol})$ in $\mathrm{ClCH}_{2} \mathrm{CH}_{2} \mathrm{Cl}(2.0 \mathrm{~mL})$ at $35^{\circ} \mathrm{C}$ for $36 \mathrm{~h}$. Yields of isolated products are reported. $\mathrm{Ar}^{1}=4-\mathrm{AcNH}-\mathrm{C}_{6} \mathrm{H}_{4} . \mathrm{Ar}^{2}$ $=4-\mathrm{TsNH}_{-} \mathrm{C}_{6} \mathrm{H}_{4}$.

The scope with respect to boronic acids 2 was next investigated (Table 2). Heteroarylboronic acids, including (5-methylthiophen-2-yl)boronic acid $\mathbf{2} \mathbf{b}$ and benzofuran2-ylboronic acid 2c, were tolerated well to obtain cyclic-product $3 \mathbf{w}$ and $\mathbf{3 x}$ in $80 \%$ and $76 \%$ yield. It is noteworthy that (1 $\mathrm{H}$-inden-2-yl)boronic acid $\mathbf{2} \mathbf{d}$ was also suitable in this reaction to give cyclopenta[a]indene bearing a quaternary carbon $3 y$ and $3 z$ in $70 \%$ and $65 \%$ yields. Furthermore, tetra-substituted allene $\mathbf{5}$ was obtained in $61 \%$ yield when (3methylbenzo[b]thiophen-2-yl)boronic acid $2 \mathrm{e}$ was reacted with propargylic alcohol 1c. Regrettably, phenyboronic acid and styrylboronic acid are not suitable for this reaction under standard conditions.

Table 3. Scope of boronic acids. ${ }^{[a]}$

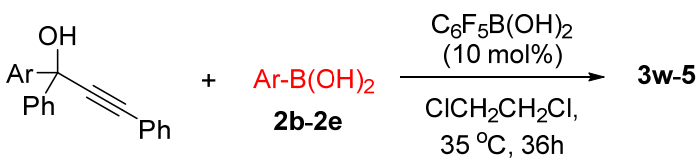

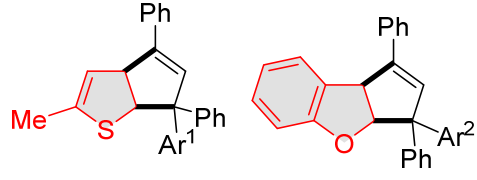

$3 \mathbf{w}(80 \%)$

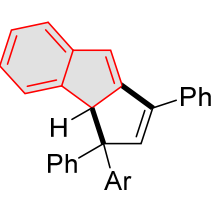

$\operatorname{Ar}=\mathrm{Ph}, \mathbf{3 y}(70 \%)$ $\mathrm{Ar}=4-\mathrm{TsNH}-\mathrm{C}_{6} \mathrm{H}_{4}, 3 \mathrm{z}$ $(d r=1 / 1,65 \%)$

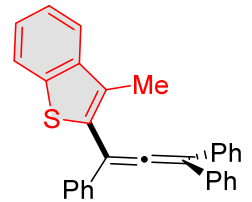

$5(61 \%)$

[a] Use of propylic alcohol $1(0.2 \mathrm{mmol})$, boronic acid 2 a $(0.24 \mathrm{mmol})$, catalyst 4 a $(0.02 \mathrm{mmol})$ in $\mathrm{ClCH}_{2} \mathrm{CH}_{2} \mathrm{Cl}(2.0 \mathrm{~mL})$ at $35^{\circ} \mathrm{C}$ for $48 \mathrm{~h}$. Yields of isolated products are reported. $\mathrm{Ar}^{1}=4-\mathrm{AcNH}^{-} \mathrm{C}_{6} \mathrm{H}_{4} . \mathrm{Ar}^{2}$ $=4-\mathrm{TsNH}-\mathrm{C}_{6} \mathrm{H}_{4}$.

To probe the reaction mechanism, several control experiments were carried out. As shown in Scheme 3a, in the presence of $10 \mathrm{~mol} \%$ or $100 \mathrm{~mol} \%$ of $\mathrm{C}_{6} \mathrm{~F}_{5} \mathrm{~B}(\mathrm{OH})_{2}$, propargylic alcohol 1a did not undergo dehydration or rearrangement at $35^{\circ} \mathrm{C}$ after reacting for $36 \mathrm{~h}$. In the absence of $\mathrm{C}_{6} \mathrm{~F}_{5} \mathrm{~B}(\mathrm{OH})_{2}$, the reaction mixture of alcohol $\mathbf{1 a}$ and boronic acid $\mathbf{2 a}$ 
became messy but no cyclic product $\mathbf{3 a}$ formed (Scheme $\mathbf{3 b}$ ), while cyclic adduct $\mathbf{3 a}$ selectively formed in $90 \%$ yield by using 10 mol\% $\mathrm{C}_{6} \mathrm{~F}_{5} \mathrm{~B}(\mathrm{OH})_{2}$ (Scheme 3c). In addition, the reaction using benzo[b]thiophene directly as nucleophile to react with propargylic alcohol 1a, no desired product obtained (Scheme 3d, For more details see the Supporting Information). These results may indicate that the boronic acid $\mathbf{2 a}$ interact strongly with $\mathbf{1 a}$, the catalyst $\mathrm{C}_{6} \mathrm{~F}_{5} \mathrm{~B}(\mathrm{OH})_{2}$ enhances the selectivity of the reaction and suppresses other side reactions.

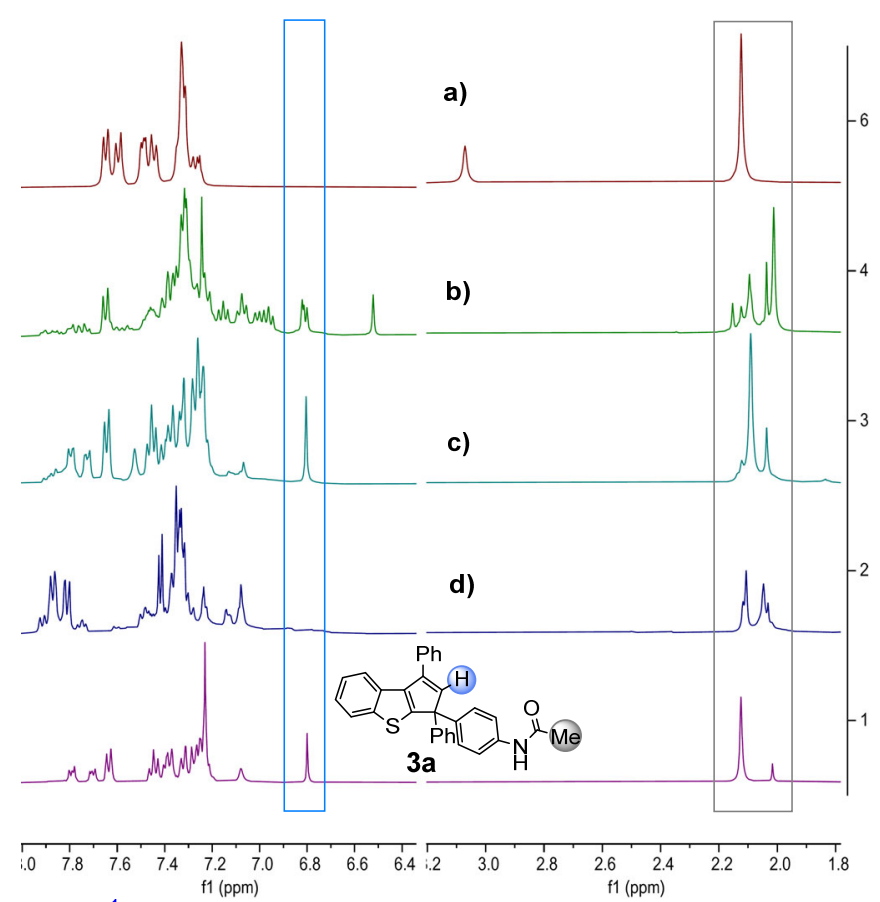

Crude ${ }^{1} \mathrm{H}$ NMR spectra of control experiment

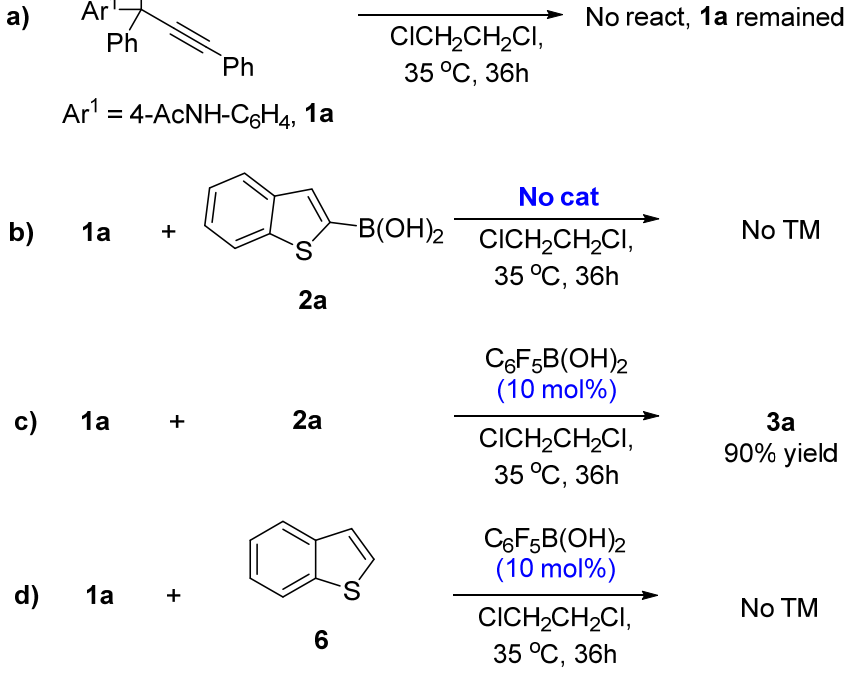

Scheme 3. Control experiments 
On the basis of our experimental results and literature precedence ${ }^{[10 d, 19]}$, we proposed a plausible reaction mechanism as show in Figure 1. First, the propargylic alcohol and boronic acid $\mathbf{2 a}$ in situ generation of the boron "ate" complex $\mathbf{7}$ and arylboronic anhydrides in the presence of catalyst $\mathrm{C}_{6} \mathrm{~F}_{5} \mathrm{~B}(\mathrm{OH})_{2}$. Boronic acid $2 \mathrm{a}$ serves as a nucleophile attacking the $\mathrm{Y}$-position of alcohol to give a four-coordinate boron ate complex $\mathbf{8}$, which then undergoes borotropic migration to obtain cyclic product 3 and boronic anhydrides 9 . Finally, Finally, the catalyst $\mathbf{4 a}$ is regenerated via a protodeboronation in $\mathbf{9}$ to lose $\mathrm{B}(\mathrm{OH})_{3}$. The formed boronic acid anhydride of $\mathbf{4 a}$ and $2 \mathrm{a}$ can stabilize complex $7 / 8$ and make the intramolecular borotropic shift relatively facile. For the $\mathrm{y}$-alkyl/TMS substituted propargyl alcohols, the intermediate 7 may first undergoes a [3,3']hydroxyl group rearrangement to furnish the allene 8'. Allene $\mathbf{8}^{\prime}$ then undergo a 1,2-aryl shift to yield allene $\mathbf{1 0}$, which further transformed into 1,3-diene by tandem proton shifts.
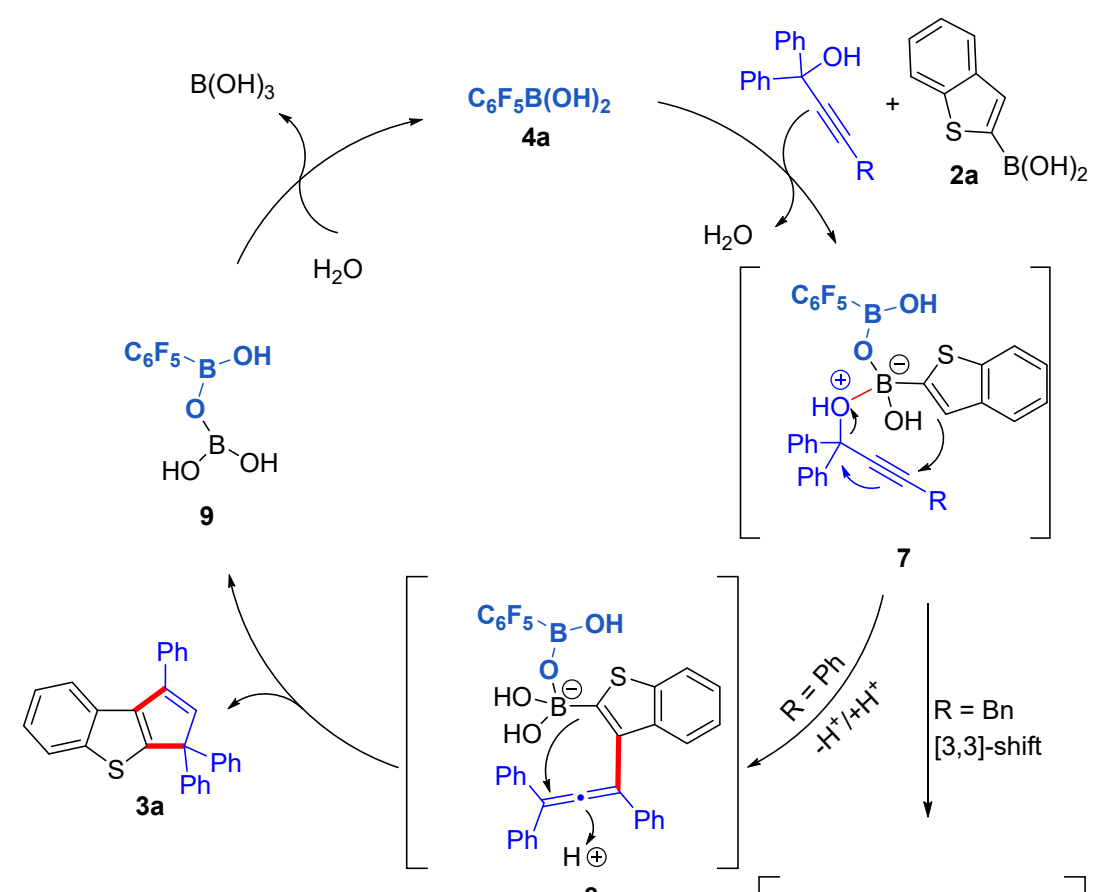

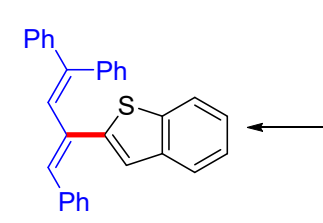

$3 s$
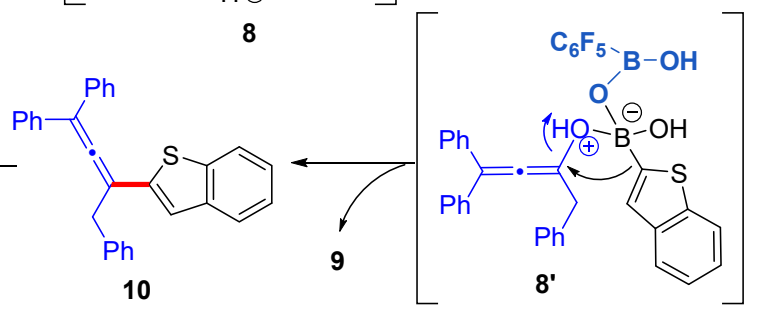

Figure 1. Plausible reaction mechanism.

In conclusion, we have developed the first examples of transition-metal-free crosscoupling reaction of tertiary propargylic alcohols with hetero-areneboronic acids. Using perfluorophenylboronic acid as catalyst under mild reaction conditions, a variety of fused benzothiophenes derivatives bearing a tetrasubstituted carbon stereocenter were efficiently constructed in moderate to good yield. In particular, this methodology presents a simple alternative for the direct construction of multi-substituted olefins. Further studies 
of this process with respect to other electrophiles are currently underway.

\section{Acknowledgements}

We are grateful for the financial supports from NSFC 22001257, NSF of Jiangsu Province (BK20211093) and acknowledge Ningbo CYC chemicals for NMR analysis.

Keywords: Metal free $\cdot$ Propargylic alcohols $•$ Perfluorophenyl boronic acid $\bullet$ Crosscoupling

[1] For selected reviews: a) S. Du, A.-X. Zhou, R. Yang, X.-R. Song, Q. Xiao, Org. Chem. Front., 2021, 8, 6760-6782; b) X.-R. Song, R. Yang, Q. Xiao, Adv. Synth. Catal., 2021, 363, 852-876; c) G. R. Kumar, M. Rajesh, S. Lin, S. Liu, Adv. Synth. Catal., 2020, 362, 5238-5256; d) X.-Y. Liu, Y.-L. Liu, L. Chen, Adv. Synth. Catal., 2020, 362, 51705195; e) H. Qian, D. Huang, Y. Bi, G. Yan, Adv. Synth. Catal., 2019, 361, 3240-3280; f) R. Roy, S. Saha, RSC Adv., 2018, 8, 31129-31193; g) L. Zhang, G. Fang, R. K. Kumara, X. Bi, Synthesis, 2015, 47, 2317-2346; h) Y. Zhu, L. Sun, P. Lu, Y. Wang, ACS Catal., 2014, 4, 1911-1925; i) D. A. Engel, G. B. Dudley, Org. Biomol. Chem., 2009, 7, 4149-4158 and references therein.

[2] a) G. Hall, Boronic Acids: Preparation and Applications in Organic Synthesis Medicine and Materials, Wiley-VCH, Weinheim, 2011, pp 1-676; b) N. Miyaura, A. Suzuki, Chem. Rev., 1995, 95, 2457-2483; c) N. Miyaura, Top. Curr. Chem., 2001, 219, $11-$ 59; c) A. F. Littke, G. C. Fu, Angew. Chem., Int. Ed., 2002, 41, 4176-4211; d) S. Roscales, A. G. Csákÿ, Chem. Soc. Rev., 2014, 43, 8215-8225; e) C. Zhu, J. R. Falck, Adv. Synth. Catal., 2014, 356, 2395-2410; f) A. J. J. Lennox, G. C. Lloyd-Jones, Chem. Soc. Rev., 2014, 43, 412-443; g) J. W. B. Fyfe, A. J. B. Watson, Chem., 2017, 3, 3155; h) I. P. Beletskaya, F. Alonso, V. Tyurin, Coord. Chem. Rev., 2019, 385, 137-173.

[3] a) B. M. Trost, C.-J. Li, Modern Alkyne Chemistry: Catalytic and Atom-Economic Transformations, Wiley- $\mathrm{VCH}$, Weinheim, 2014. b) J. Corpas, P. Mauleón, R. G. Arrayás, J. C. Carretero, ACS Catal., 2021, 11, 7513-7551; c) T. Hayashi, K. Inoue, N. Taniguchi, J. Am. Chem. Soc., 2001, 123, 9918-9919; d) C. H. Oh, H. H. Jung, K. S. Kim, N. Kim, Angew. Chem., Int. Ed., 2003, 42, 805-808; e) M. R. Wilson, R. E. Taylor, Angew. Chem., Int. Ed., 2013, 52, 4078-4087; f) R. Chinchilla, C. Nájera, Chem. Rev. 2014, 114, 1783-1826; g) J. Chen, J. Guo, Z. Lu, Chin. J. Chem., 2018, 36, 1075-1109; h) C. Lin, L. Shen, ChemCatChem, 2018, 11, 961-968; i) Z. Cheng, J. Guo, Z. Lu, Chem. Commun., 2020, 56, 222-2239; j) S. Ghosh, D. Lai, A. Hajra, Org. Biomol. Chem., 2020, 18, 7948-7976.

[4] M. Yoshida, T. Gotou, M. Ihara, Tetrahedron Lett., 2004, 45, 5573-5575

[5] a) N. Liu, Y. Zhi, J. Yao, J. Xing, T. Lu, X. Dou, X. Adv. Synth. Catal., 2018, 360, 642646; b) A. Qin, H. Qian, Q. Chen, S. Ma, Chin. J. Chem., 2020, 38, 372-382; c) J. Xing, Y. Zhu, X. Lin, N. Liu, Y. Shen, T. Lu, X. Dou, Adv. Synth. Catal., 2018, 360, 1595-1599; d) Y. Yao, G. Zhu, Q. Chen, H. Qian, S. Ma, Org. Chem. Front., 2019, 6, 304-308; e) J. Xiao, H. Luo, S. Huang, H. Qian, S. Ma, Chem. Commun., 2018, 54, 10451-10454. 
[6] a) M. J. Ardolino, J. P. Morken, J. Am. Chem. Soc., 2012, 134, 8770-8773; b) X. Huang, S. Wu, W. Wu, P. Li, G. C. Fu, S. Ma, S. Nat. Commun., 2015, 6, 7946-7954; c) V. Franckevičius, Tetrahedron Letters, 2016, 57, 3586-3595.

[7] N. Liu, J. Yao, L. Yin, T. Lu, Z. Tian, X. Dou, ACS Catal., 2019, 9, 6857-6863.

[8] a) Y. Pang, G. Liu, C. Huang, X.-A. Yuan, W. Li, J. Xie, Angew. Chem., Int. Ed., 2020, 59, 12789-12794; b) W. Wang, H. Qian, S. Ma, Chin. J. Chem., 2020, 38, 331-345; c) Z. Yan, X.-A. Yuan, Y. Zhao, C. Zhu, J. Xie, Angew. Chem., Int. Ed., 2018, 57, 12906-12910.

[9] S. Liao, H. Xu, L. Xu, B. Liang, B. Yang, J. Wang, X. Zhou, X. Lin, Z. Luo, Y. Liu, Tetrahedron, 2021, 77, 131764-131772.

[10] a) J.-F. Bai, K. Yasumoto, T. Kano, K. Maruoka, Angew. Chem., Int. Ed., 2019, 58, 8898-8901; b) J.-F. Bai, L. Zhao, F. Wang, F. Yan, T. Kano, K. Maruoka, Y. Li, Org. Lett., 2020, 22, 5439-5445.

[11] a) N. R. Candeias, F. Montalbano, P. M. S. D. Cal, P. M. P. Gois, Chem. Rev., 2010, 110, 6169-6193; b) P. Wu, M. Givskov, T. E. Nielsen, Chem. Rev., 2019, 119, 1124511290; c) N. A. Petasis, I. A. Zavialov, J. Am. Chem. Soc., 1998, 120, 11798-11799.

[12] a) D. Tian, C. Li, G. Gu, H. Peng, X. Zhang, W. Tang, Angew. Chem., Int. Ed., 2018, 57, 7176-7180; b) C. Zhu, J. R. Falck, Adv. Synth. Catal., 2014, 356, 2395-2410; c) S. Roscales, A. G. Csákÿ, Chem. Soc. Rev., 2014, 43, 8215-8225; d) A. Bonet, M. Odachowski, D. Leonori, S. Essafi, V. K. Aggarwal, Nature Chem., 2014, 6, 584-589.

[13] a) Priviledged scaffolds in medicinal chemistry:design, synthesis, evaluation (Ed.: S. Bräse), RSC, London, 2015; b) D. Morgan, S. J. Yarwood, G. Barker, Eur. J. Org. Chem., 2021, 1072-1102; c) S. Han, J. E. Sweeney, E. S. Bachman, E. J. Schweiger, G. Forloni, J. T. Coyle, B. M. Davis, M. M. Joulli, Eur. J. Med. Chem., 1992, 27, 673687; d) C. D. Jones, L. C. Blaszczak, M. E. Goettel, T. Suarez, T. A. Crowell, T. E. Mabry, P. C. Ruenitz, V.Srivatsan V, J. Med. Chem., 1992, 35, 931-938; e) M. G. Bell, B. S. Muehl, M. A. Winter, U.S. Patent US5,856,341, 1999; f) G. Schulz, C. Victoria, A. Kirschning, E. Steinmann, Nat. Prod. Rep., 2021, 38, 18-23; g) A. Rinaldi, D. Scarpi, E. G. Occhiato, Eur. J. Org. Chem., 2019, 7401-7419.

[14] a) L. Berrade, B. Aisa, M. J. Ramirez, S. Galiano, S. Guccione, L. R. Moltzau, F. O. Levy, F. Nicoletti, G. Battaglia, G. Molinaro, I. Aldana, A. Monge, S. Perez-Silanes, J. Med. Chem., 2011, 54, 3086-3090; b) R. S. Keri, K. Chand, S. Budagumpi, S. Balappa Somappa, S. A. Patil, B. M. Nagaraja, Eur. J. Med. Chem., 2017, 138, 1002-1033; c) C. Wang, H. Dong, W. Hu, Y. Liu, D. Zhu, Chem. Rev., 2012, 112, 2208-2267; d) R. Sang, A. Noble, V. K. Aggarwal, Angew. Chem., Int. Ed., 2021, 60, 25313-25317

[15] a) X. Li, D. G. Hall, Adv. Synth. Catal., 2021, 363, 2209-2223; b) N. Y. Adonin, V. V. Bardin, Mendeleev Commun., 2020, 30, 262-272; c) S. Zhang, D. Lebœuf, J. Moran, Chem. Eur. J., 2020, 26, 9883-9888; d) D. G. Hall, Chem. Soc. Rev., 2019, 48, 34753496; e) E. Dimitrijevic, M. S. Taylor, ACS Catal., 2013, 3, 945-962; f) Y. Zhu, L. Sun, P. Lu, Y. Wang, ACS Catal., 2014, 4, 1911-1925; g) J. A. McCubbin, C. Nassar, O. V. Krokhin, Synthesis, 2011, 19, 3152-3160; h) H. Zheng, S. Ghanbari, S. Nakamura, D. G. Hall, Angew. Chem., Int. Ed., 2012, 51, 6187-6190. 
[11] a) D. Tian, C. Li, G. Gu, H. Peng, X. Zhang, W. Tang, Angew. Chem., Int. Ed., 2018, 57, 7176-7180; b) N. A. Petasis, I. A. Zavialov, J. Am. Chem. Soc., 1998, 120, 1179811799.

[17] CCDC 2122663 (3p) contains the supplementary crystallographic data for this paper. These data can be obtained free of charge from The Cambridge Crystallographic Data Centre.

[18] a) N. Cabrera-Lobera, N. Velasco, R. Sanz, M. A. Fernandez-Rodriguez, Tetrahedron, 2019, 75, 4071-4080; b) M. Shao, Y. Wu, Z. Feng, X. Gu, S. Wang, Org. Biomol. Chem., 2016, 14, 2515-2521; c) R. Sanz, D. Miguel, A. Martínez, M. Gohain, P. García-García, M. A. Fernández-Rodríguez, E. Álvarez, F. Rodríguez, Eur. J. Org. Chem., 2010, 2010, 7027-7039.

[19] a) K. Yang, X. Hu, W. Li, J. Qiu, Q. Feng, S. Wang, G. Zhang, Z. Kuang, P. Yu, Q. Song, Cell Rep. Phys. Sci., 2020, 1, 100268-100283; b) K. Yang, F. Zhang, T. Fang, G. Zhang, Q. Song, Angew. Chem., Int. Ed., 2019, 58, 13421-13426. 